J. Amer. Soc. Hort. Sci. 126(2):175-181. 2001.

\title{
Particle Film Application Influences Apple Leaf Physiology, Fruit Yield, and Fruit Quality
}

\author{
D. Michael Glenn ${ }^{1}$ and Gary J. Puterka ${ }^{2}$ \\ U.S. Department of Agriculture, Agricultural Research Service, Appalachian Fruit Research Station, 45 \\ Wiltshire Road, Kearneysville, WV 25430
}

Stephen R. Drake ${ }^{3}$

U.S. Department of Agriculture, Agricultural Research Service, Tree Fruit Research Laboratory, 1104 N. Western Avenue, Wenatchee, WA 988001-1299

Thomas R. Unruh ${ }^{4}$ and Allen L. Knight ${ }^{4}$

U.S. Department of Agriculture, Agricultural Research Service, Yakima Agricultural Research Laboratory, 5230 Konowac Pass Road, Wapato, WA 98951

Pedro Baherle $^{5}$ and Ernesto Prado
Instituto de Investigaciones Agropecuarias Centro regional de Investigacion. Casilla 439-3, Santiago, Chile

Tara A. Baugher ${ }^{7}$

Rice Fruit Company, 2760 Carlisle Road, Gardners, PA 17324-0066

\begin{abstract}
ADDITIONAL INDEX WORDS. Malus sylvestris var. domestica, heat stress, carbon assimilation, canopy minus air temperature, fruit quality
Abstract. Particle film technology is a developing pest control system for tree fruit production systems. Trials were performed in Santiago, Chile, and York Springs, Pa., Wenatchee and Yakima, Wash., and Kearneysville, W. Va., to evaluate the effect of particle treatments on apple [Malus sylvestris (L.) Mill. var.domestica (Borkh) Manst.] leaf physiology, fruit yield, and fruit quality. Leaf carbon assimilation was increased and canopy temperatures were reduced by particle treatments in seven of the eight trials. Yield and/or fruit weight was increased by the particle treatments in seven of the eight trials. In Santiago and Kearneysville, $a^{*}$ values of the fruit surface were more positive in all trials although $a^{*}$ values were not increased in Wenatchee and Yakima. Results indicate that particle film technology is an effective tool in reducing heat stress in apple trees that may result in increased yield potential and quality.
\end{abstract}

Environmental dusts and particulate coverings on plants generally reduce photosynthesis and productivity (Farmer, 1993; Hirano et al., 1995) due to leaf shading and interference with stomatal activity. However, particulate sprays have been applied to increase foliage reflectivity and reduce heat load on plants with some increases in plant productivity.

Abou-Khaled et al. (1970) found that a reflective kaolin spray decreased leaf temperature by increasing leaf reflectance and reduced transpiration more than photosynthesis at high solar radiation levels in species which are light saturated at low irradiances. Doraiswamy and Rosenberg (1974) coated soybean [Glycine max (L.) Merrill] plants with kaolinite to increase reflection of incident radiation and found that net radiation was reduced $8 \%$ and shortwave radiation was reduced $20 \%$, suggesting a potential reduction in transpiration and water use. Basnizki and Evenari (1975) applied a reflectant coating to globe artichoke (Cynara scolymus L.) and reduced leaf temperature, increased water use efficiency, and increased plant survival. Stanhill et al. (1976) applied kaolin to grain sorghum (Sorghum bicolor Moench) and increased yield by $11 \%$

Received for publication 15 Nov. 1999. Accepted for publication 23 Oct. 2000. The authors wish to thank the Washington State Tree Fruit Commission and the Engelhard Corporation for their financial support of this research. The cost of publishing this paper was defrayed in part by the payment of page charges. Under postal regulations, this paper therefore must be hereby marked advertisement solely to indicate this fact.

${ }^{1}$ Soil scientist; e-mail: mglenn@afrs.ars.usda.gov.

${ }^{2}$ Entomologist; e-mail: gputerka@afrs.ars.usda.gov.

${ }^{3}$ Horticulturist.

${ }^{4}$ Entomologist.

${ }^{5}$ Agronomist.

${ }^{6}$ Entomologist.

${ }^{7}$ Horticulturist. over a 3-year period despite a reduction in the rate of $\mathrm{CO}_{2}$ uptake and early leaf senescence. Moreshet et al. (1979) sprayed kaolin on cotton (Gossypium lirsutum L.) and caused an $11 \%$ increase in yield the first year but found no increase the second year. Kaolin treatments reduced ${ }^{14} \mathrm{CO}_{2}$ uptake due to a reduction in light absorption and partially blocked the stomata resulting in reduced water stress. Soundara Rajan et al. (1981) increased yield, pod number, and test weight of peanuts (Arachis hypogaea L.) by applying kaolin under dry land conditions. Rao (1985) applied kaolin to nonirrigated tomato (Lycopersicon esculentum Mill) and demonstrated that the reflective kaolin improved the water status and yield of nonirrigated plants compared to the nontreated controls.

It appears that applying a reflective coating to plants under water stress provides more benefit in reducing the heat load than reduction in potential photosynthesis. Glenn et al. (1999) demonstrated that a dusted particle film did not reduce carbon assimilation in potted apple (Malus sylvestris var. domestica) peach [Prunus persica (L.) Batsch (Peach Group)], and pear (Pyrus communis L.) in growth chamber conditions with an irradiance of $900 \mu \mathrm{mol} \cdot \mathrm{m}^{-2} \cdot \mathrm{s}^{-1}$. They also applied this reflective dust film to peach trees in a field study and observed no reduction in fruit yield or quality, however, leaf temperature was reduced. Glenn et al. (1999) demonstrated that particle films have broad disease and insect control potential in tree fruit crops. Therefore, the following research utilized an aqueous formulation of a particle film of Glenn et al., (1999) and examined the effect on apple leaf physiology, yield components, and fruit quality in varying environments.

Materials

\section{Methods and Materials}

Apple trees received applications of a highly reflective, white, 
hydrophobic particle (M96-018, Engelhard Corp., Iselin, N.J.) following bloom in addition to a conventional pesticide spray program. M96-018 kaolin utilizes a kaolin mineral processed to a bright white color of $>85 \%$, with mean particle size $<2 \mu \mathrm{m}$ in diameter, that is surface treated with a proprietary hydrocarbon to render it hydrophobic. The M96-018 treatment was prepared by first mixing the particles with methanol to wet them and then the particle-methanol slurry was added to water. The final mixture contained 3\% (w/v) M96-018 and 4\% (v/v) methanol in water (Sekutowski et al., 1999). The M96-018 mixture and the conventional treatment were applied to runoff using a handgun sprayer or air blast sprayer, as specified.

\section{Physiological and fruit quality parameters}

Carbon assimilation (A) and stomatal conductance (Gs) were measured at various times during a clear sky day using a photosynthesis system (LI-6200; LI-COR, Lincoln, Nebr.) in 1997. Two leaves/tree were enclosed individually in the cuvette. Measurements were completed within 60 to 90 s of enclosure. Undamaged, mature leaves from the distal five leaves on an exposed branch and leaves with similar levels of M96-018 residue were chosen for measurement. In 1998, a combined infrared gas analysis system (CIRAS-1; PP Systems, Haverville, Mass.) with an external light source was used to measure A and Gs. In 1998, A was measured at a photosynthetic photon flux $(P P F)$ of $1000 \mu \mathrm{mol} \cdot \mathrm{m}^{-2} \cdot \mathrm{s}^{-1}$, otherwise the sampling procedures were the same as 1997. Fruit surface temperature was measured at solar noon using an IR thermometer (model 110; Everest Interscience, Tustin, Calif.). The canopy-air temperature differential $(\Delta \mathrm{T})$ was measured at each sampling hour with the IR thermometer. About $1 \mathrm{~m}^{2}$ of the canopy was in the IR thermometer's field of view and the illuminated portion of the tree was measured. Air temperature was measured with a thermistor located on the infrared thermometer.

Ten mature leaves were collected from the distal fifth to tenth leaf position for chlorophyll analysis. Leaves were detached and placed on ice and frozen at $-80^{\circ} \mathrm{C}$ within $30 \mathrm{~min}$ of removal. Chlorophyll was extracted by placing discs of known area in liquid $\mathrm{N}$ and crushing with a mortar and pestle. Acetone $(80 \%+20 \%$ water $)$ was added to the leaf tissue. Chlorophyll $\mathrm{a}$ and $\mathrm{b}$ and total chlorophyll were extracted and analyzed spectrophotometrically according to MacKinney (1941).

In all studies, fruit were harvested at optimum maturity for storage based on firmness, starch, and soluble solids concentration (SSC). In some cases, the particle film treatments delayed harvest by 1 to $2 \mathrm{~d}$. Unless otherwise specified, 10 randomly selected fruit per plot were collected at harvest and shipped to the U.S. Department of Agriculture, Agriculture Research Service (USDA/ARS) Wenatchee, for quality evaluation. Firmness was determined using the TA-XT2 Texture Analysis System (Texture Technologies Corp., Scarsdale, N.Y.) equipped with a $11.1 \mathrm{~mm}$ probe. External color was determined using the Commission Internationale d'Eclairage (CIE) $\mathrm{L}^{*}, \mathrm{a}^{*}, \mathrm{~b}^{*}$ color space coordinates. Three values for color were determined around the circumference of each fruit. SSC and titratable acidity (TA) were determined from an aliquot of expressed juice of a longitudinal slice from each of 10 fruit. SSC was measured with an Abbetype refractometer(model 10450, American Optical Scientific Instruments Div., Buffalo, N.Y.) with a sucrose scale calibrated at $20^{\circ} \mathrm{C}$. TA was measured with a radiometer titrator(model TTT85, Radiometer, Copenhagen, Sweden). Acids were titrated to $\mathrm{pH} 8.2$ with $0.1 \mathrm{~mol} \cdot \mathrm{L}^{-1} \mathrm{NaOH}$ and expressed as percentage malic acid.

\section{Study sites}

SAnTIAGO, 1997. The apple orchard was a high density, trellis planting (1000 trees/ha) of 'Red Chief'/Malling 26 (M.26), located $\approx 100 \mathrm{~km}$ south of Santiago. The trees were furrow irrigated on an 8$\mathrm{d}$ basis and hand thinned postbloom. There were three treatments: 1) 12 weekly applications of M96-018 following bloom, 2) a conventional pesticide spray program, and 3) a nontreated control. About 1.5 L of 3\% M96-018 was applied per tree. Treatments were applied with a handgun sprayer. Conventional orchard practices were used for training and weed control. The experiment was a randomized block design with 12 trees/plot and five replications. In February 1997, 3 weeks before harvest, A, Gs, and $\Delta \mathrm{T}$, were measured on three consecutive cloud-free days, at 1000, 1100, 1300, 1500, and 1700 HR from the center tree in each plot. Fruit surface temperature was measured on 50 fruit/plot from the center trees of each plot on only the first day at solar noon. At harvest, total fruit number and fruit weight from the center 10 trees/plot were recorded. Red color ( $a^{*}$ value) of 10 fruit randomly selected from the harvested plot sample was measured using a chromometer (model CR221; Minolta Corp., Ramsey, N.J.). Color was measured at four locations around the circumference of each fruit. Particle density on the leaves was measured after application by wash-off with deionized water into a preweighed beaker, and ranged from 800 to 1000 $\mu \mathrm{g} \cdot \mathrm{cm}^{-2}$.

YAKIMA, 1997. The apple orchard was a moderate density planting (485 trees/ha) of 'Red Spur Delicious'/M.111 located adjacent to the USDA/ARS Fruit Research Laboratory near Wapato, Wash. The trees were under-tree sprinkler irrigated on a weekly basis and hand thinned postbloom. There were three treatments: 1) seven applications of M96-018 throughout the growing season, 2) 10 more closely spaced applications of M96-018 throughout the growing season, and 3) a nontreated control. About $4 \mathrm{~L}$ of 3\% M96-018 was applied per tree. The M96-018 mixture was applied to drip using an air blast sprayer. Conventional orchard practices were used in training and weed control. The experiment was a randomized block design with six trees/plot and three replications. In August 1997, 5 weeks before harvest, $\mathrm{A}$, Gs, and $\Delta \mathrm{T}$ were measured on four consecutive cloud-free days at 900, 1200, 1300, and $1500 \mathrm{HR}$. At harvest, 30 fruit from the upper half of the canopy and 30 fruit from the lower half of the canopy were collected per tree and the six trees were pooled for plot weight and number. Fruit quality was evaluated by USDA/ARS Wenatchee using the Color Machine (Pacific Scientific, Silver Spring, Md.). Red color (a* value) was measured on 20 fruit/plot from fruit randomly selected from the harvested plot. Particle density on the leaves was measured by wash-off with water into a preweighed beaker and ranged from 150 to $250 \mu \mathrm{g} \cdot \mathrm{cm}^{-2}$. Leaf samples were collected for chlorophyll analysis in July.

KEARNEYSVILLE, 1997. The apple orchard was a moderate density planting (400 trees/ha) of 'Bisbee Red Spur Delicious'/M.111 located at the USDA/ARS Appalachian Fruit Research Station, Kearneysville. The trees were nonirrigated and were not thinned postbloom. The three treatments were 15 weekly applications of M96-018 throughout the growing season 2) a nontreated control, and 3 ) a conventional pest control program. About $4 \mathrm{~L}$ of $3 \% \mathrm{M} 96-$ 018 was applied per tree. The M96-018 mixture was applied to runoff using an air blast sprayer. Conventional orchard practices were used in training and weed control. The experiment was a randomized block design with three trees per plot and four replications. In August 1997, 3 weeks before harvest, A, Gs, and $\Delta \mathrm{T}$ were measured on two cloud-free days at 1000 and 1400 HR. At harvest, all fruit were collected, counted, and weighed on a plot basis. Fruit color was evaluated by USDA/ARS, Wenatchee. Stem water potential was measured on leaves covered with foil at sunset of the previous day. The stem water potential was measured with a pressure chamber at 1000 and 1400 HR. Stem water potential was 
measured on two leaves/plot at each sampling time. Particle density on the leaves was measured using a chromometer (model CR221; Minolta Corp.) as described by Glenn et al. (1999) and ranged from 300 to 500 $\mu \mathrm{g} \cdot \mathrm{cm}^{-2}$. Leaf samples for chlorophyll analysis were collected in July.

YORK SPRINGS, 1997. The apple orchard was a low density planting (205 trees/ha) of 'Golden Delicious'/seedling rootstock located at the Cloverdale Orchard near Gettysburg, Pa. The trees were nonirrigated and chemically thinned. Chemical thinning sprays were applied after the initial applications of M96-018. The three treatments were 1) conventional pest control treatment, 2) eight applications of 3\% M96-018, and 3) eight applications of 1.5\% M96-018 and 2\% methanol in water. The M96-018 mixture was applied to drip using an air blast sprayer. About $10 \mathrm{~L}$ of M96-018 was applied per tree in treatments 2 and 3. Conventional orchard practices were used in training, thinning, and weed control. The experiment was a randomized block design with 0.5 ha plots of each treatment and two replications. At harvest, 20 fruit from six randomly selected trees per replicate were weighed. Fruit diameter, russet incidence and severity, and $\mathrm{L}^{*}, \mathrm{a}^{*}$, and $\mathrm{b}^{*}$ color space coordinates were measured on each fruit. Color was determined with a scanning spectrophotometer (Colortron; Light Source, Larkspur, Calif.). Particle density on the leaves was not measured but was estimated visually at 100 to $300 \mu \mathrm{g} \cdot \mathrm{cm}^{-2}$.

WeNATCHEE, 1998. The apple orchard was a high density planting (980 trees/ha) located near the USDA/ARS Fruit Research Laboratory, Wenatchee. The trees were under-tree sprinkler irrigated on a weekly basis and were chemically thinned postbloom following the initial application of M96-018 for the May application treatment. 'Oregon Spur'/M.7 and 'Starkrimson Delicious'/M.7 received varying applications of M96-018 in addition to a nontreated control. The M96-018 mixture was applied to runoff using an orchard sprayer. About 2 L of 3\% M96-018 was applied per tree. Conventional orchard practices were used in training and weed control. The experiment was a randomized block design with three trees/plot and six replications. The treatments were the time of initiating particle application: May, June, July, August, and September. After the first application, treatments were reapplied every 14 d until harvest. In September 1998, $21 \mathrm{~d}$ before harvest, A, and Gs were measured on the center tree per plot for three consecutive cloud-free days when air temperature did not exceed $25^{\circ} \mathrm{Cat} 1000$ and $1500 \mathrm{HR}$. Because the largetrees atclose spacing prevented an adequate view of the canopy, $\Delta \mathrm{T}$ was not measured. At harvest, all fruit per plot were measured and yield and average fruit weight of 20 randomly selected fruit were recorded. Fruit color was evaluated by USDA/ARS, Wenatchee. Fruit number was calculated by dividing total plot yield by average fruit size. Particle density on the leaves was measured using a chromometer (model CR221; Minolta Corp.) with the methodology of Glenn et al. (1999), and ranged from 100 to $500 \mu \mathrm{g} \cdot \mathrm{cm}^{-2}$.

KEARNEYSVILLE, 1998. The apple orchard was a moderate density planting (500 trees/ha) of 'Empire'/M.7A located at the USDA/ ARS Appalachian Fruit Research Station, Kearneysville. The trees were nonirrigated and were not thinned postbloom. Trees were treated with M96-018 or were nontreated. All treatments were oversprayed with conventional pesticides to insure no insect damage. The M96-018 mixture was applied to runoff using an air blast sprayer. About 4 L of 3\% M96-018 was applied per tree. Conventional orchard practices were used in training and weed control. The experiment was a randomized block design with three trees/plot and six replications. The treatments were the time of initiating particle application: May, June, July, and August. After the first application, treatments were reapplied every $7 \mathrm{~d}$ until harvest. A and Gs were measured on $5 \mathrm{~d}$ in Augustand September at $1300 \mathrm{HR}$ from the center tree of each plot. Because the dates of A measurement were partly cloudy, $\Delta \mathrm{T}$ was not measured. At harvest, all fruit were weighed and counted in each plot. Fruit color was evaluated by USDA/ARS, Wenatchee. Five leaves per tree were collected in July and August for chlorophyll analysis. Particledensity on the leaves was measuredusing achromometer(model CR221; Minolta Corp.) with the methodology of Glenn et al. (1999) and ranged from 300 to $500 \mu \mathrm{g} \cdot \mathrm{cm}^{-2}$.

\section{Data analysis}

Data were subjected to analysis of variance procedures based on the experimental design. Treatment means were compared using Fisher's protected least significant difference (LSD), $P=0.05$.

\section{Results}

SANTIAGo, 1997. The date $\times$ treatment interaction was not significant for gas exchange data, so data were pooled over dates. The M96-018 treatment had higher leaf carbon assimilation at 1000, 1100, and $1300 \mathrm{HR}$ (Fig. 1A) and higher stomatal conductance (Fig. 1B) than the conventional or nontreated control at 1000, 1100, 1300, and $1500 \mathrm{HR}$. Canopy-air $\Delta \mathrm{T}$ was also lower for the M96-018 treatment throughout the day (Fig. 1C). The M96-018 leaf-air $\Delta \mathrm{T}$ from the cuvette was lower than the conventional treatment for all hours of sampling, and the control was intermediate. Fruit surface temperature was lower for the M96-018 treatment compared to the conventional and nontreated control (34.5 vs. 35.8 , and $35.5^{\circ} \mathrm{C}$, respectively, $P=0.05, \mathrm{n}=6$ ). Yield and average fruit weight were not affected by the treatments, however, $a^{*}$ value was increased by the M96-018 treatment (Table 1).

Y AKIMA, 1997. There was some leafhopper [Empoasca fabae (Harris)] stippling in the nontreated control trees but leaves chosen for assimilation were free of visible leafhopper damage and were otherwise healthy. There was a significant treatment $\times$ date of sampling interaction forcarbonassimilation, stomatalconductance, and $\Delta \mathrm{T}$. There was a typical late afternoon depression in A, but both M96018 treatments had less of a reduction compared to the control at 1100 , 1300, and $1500 \mathrm{HR}$ on all (Fig. 2A). Gs was higher for the particle film treatments at all dates and times except the morning of 17 July (Fig. 2B). Canopy $\Delta \mathrm{T}$ was more negative on all days for the 1300 and $1500 \mathrm{HR}$ measurements of the particle film treatments compared to the control except for 18 July (Fig. 2C) and the seven applications of M96-018 on 17 July. The $\Delta \mathrm{T}$ within the cuvette for both M96-018 treatments generally had lower $\Delta \mathrm{T}$ values than the control (Fig. 2C). Fruit weight increased with additional applications of M96-018 and both particle film treatments increased fruit weight over the control (Table 2). Treatment did not influence $\mathrm{a}^{*}$ values (Table 2 ). Leaf chlorophyll content, soluble solids, acidity and firmness were not significantly affected by the treatments (data not presented).

KearneysviLle, 1997. There was not a significant treatment $\times$ sampling date interaction for $\mathrm{A}, \mathrm{Gs}, \Delta \mathrm{T}$ or stem water potential, so data were pooled for the 2 sampling days. A and Gs were significantly higher for the particle treatment than for the conventional treatment (Table 3). Leaf and canopy $\Delta \mathrm{T}$ and stem water potential were more negative for the particle film treatments compared to the control (Table 3). Yield was higher for the particle film treatment due to decreased preharvest fruit drop compared to the conventional and control treatments (Table 4). The control trees had severe defoliation due to disease and insect damage. Although the particle film-treated trees had the most fruit, fruit weight was equivalent to the conventional treatment and greater than the nontreated. Also, $\mathrm{a}^{*}$ values were highest for the particle film and the control treatment (Table 4) than for the conventional treatment. SSC, TA, and 
firmness were not significantly affected by the treatments (data not presented).

York Springs, 1997. Fruit size was greatest for the $3 \%$ rate of M96-018 than for the 1.5\% M96-018 and conventional treatment (Table 5). Both M96-018 treatments reduced the percentage of fruit with russeting and the severity of russeting compared to the conventional treatment. Percentages of fruit downgraded due to russet were 13.8, 3.3, and 2.9 for conventional, 3\% M96-018, and 1.5\% M96018 , respectively $(P=0.05)$. Fruit treated with $1.5 \%$ M96-018 had more positive $b^{*}$ values than conventionally treated fruit.

Wenatchee, 1998. Despite chemical thinning, particle film ap-
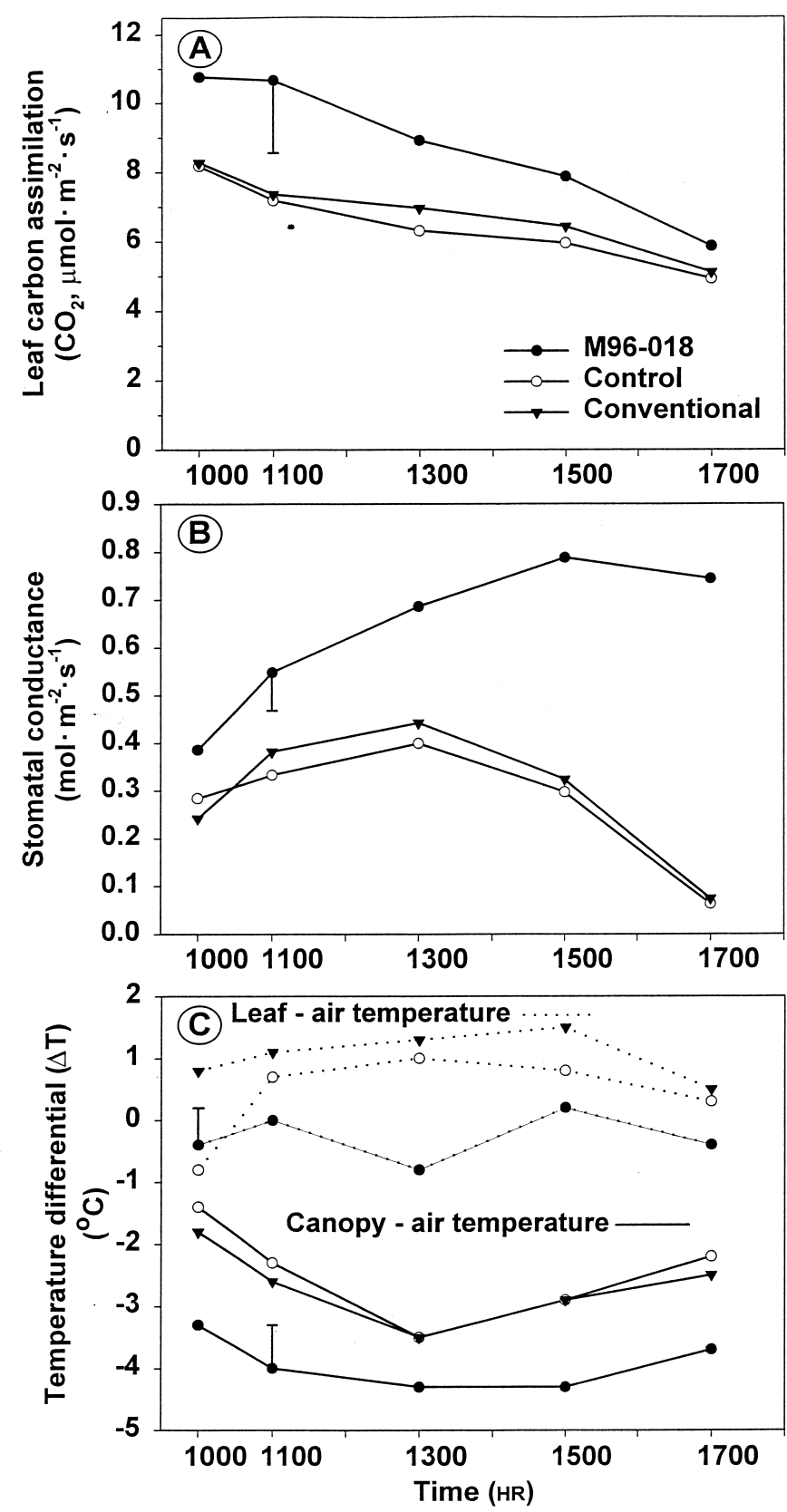

Fig. 1. (A) Leaf carbon assimilation, (B) stomatal conductance, and (C) leaf-air temperature or canopy-air temperature differential $(\Delta \mathrm{T})$ of 'Red Chief' apple in Santiago, Chile, treated with a particle film treatment (M96-018), nontreated control, or conventional pesticides. Data are pooled over a 3-d period. The protected LSD $(P \leq$ $0.05, \mathrm{n}=15$ ) for the analysis is represented by the vertical bars in each figure. plication increased yield due to increased fruit number when treatments were initiated in May or June for 'Starkrimson Red Delicious' (Table 6) and in June for 'Oregon Spur Delicious' (Table 7). Fruit weight and $\mathrm{a}^{*}$ values were not affected by the time of treatment. SSC, TA, and firmness were not significantly affected by the treatments (data not presented). There was not a significant sampling time $(1000 \mathrm{vs} .1400 \mathrm{HR}) \times$ sampling date interaction, so the data were pooled over sampling time and date for each experiment. Treatments did not influence A of 'Starkrimson Delicious', however for 'Oregon Spur Delicious' the particle treatments generally reduced A compared to the conventional treatment (Table 8). Leaf
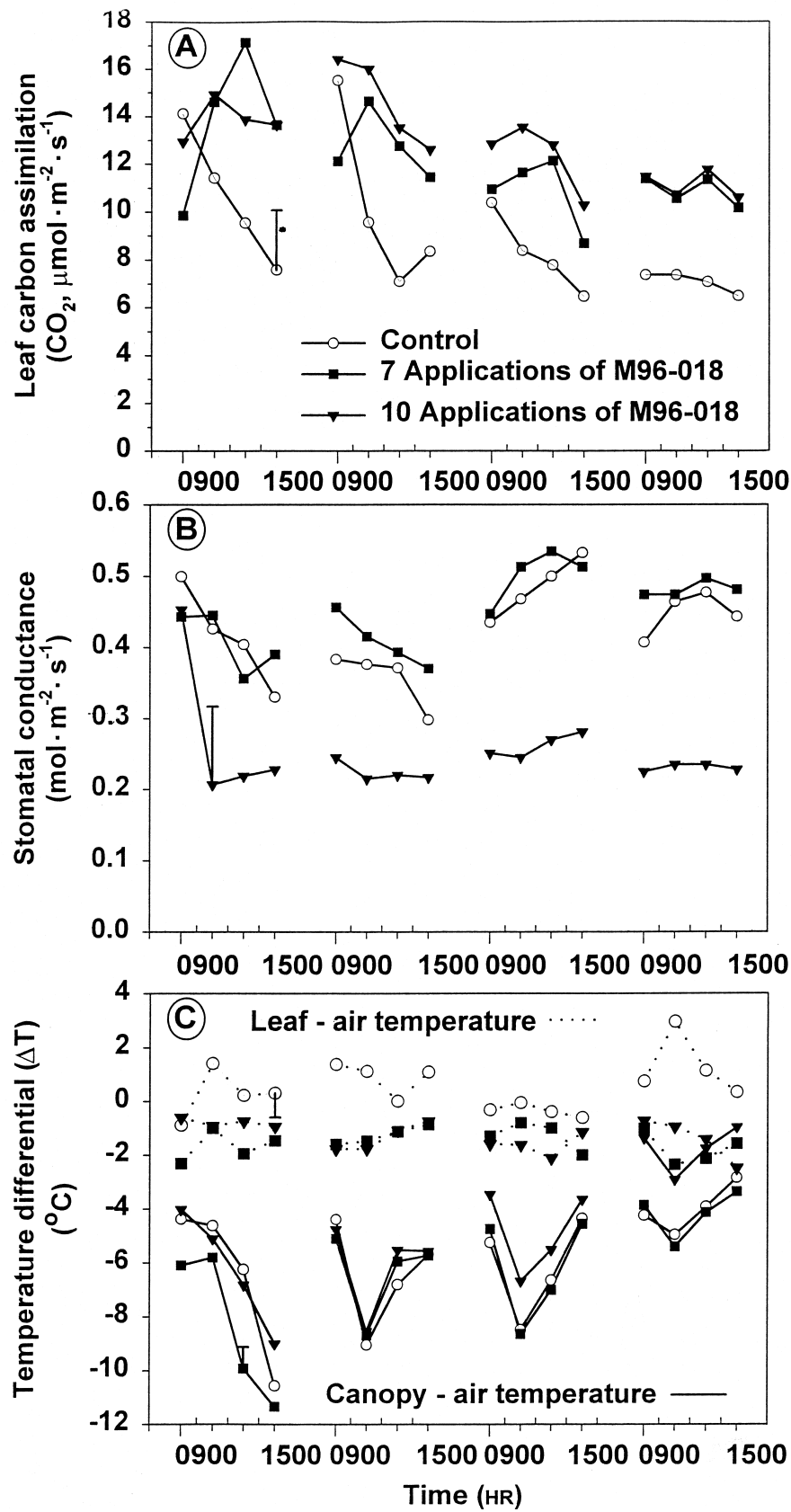

Fig. 2. (A) Leaf carbon assimilation, (B) stomatal conductance, and (C) leaf-air temperature or canopy-air temperature differential $(\Delta \mathrm{T})$ of 'Red Spur Delicious' in Yakima, Wash., receiving 0,7 , or 10 applications of a particle film. The protected LSD $(P \leq 0.05, \mathrm{n}=12)$ for the analysis is represented by the vertical bar in each figure. 
Table 1. Fruit per tree, fruit weight, yield, and a* values of 'Red Chief Delicious' fruit as influenced by treatment with a particle film (Santiago, Chile, 1997).

\begin{tabular}{lccc}
\hline \hline Treatment & $\begin{array}{c}\text { Fruit/tree } \\
\text { (no.) }\end{array}$ & $\begin{array}{c}\text { Fruit wt } \\
\text { (g/fruit) }\end{array}$ & $\begin{array}{c}\text { Yield } \\
(\mathrm{kg} / \text { tree) }\end{array}$ \\
\hline M96-018 & $139 \mathrm{a}^{\mathrm{z}}$ & $171 \mathrm{a}$ & $23.7 \mathrm{a}$ \\
Conventional & $156 \mathrm{a}$ & $179 \mathrm{a}$ & $27.8 \mathrm{a}$ \\
Control & $130 \mathrm{a}^{\mathrm{z}}$ & $169 \mathrm{a}$ & $36.1 \mathrm{a}$ \\
\end{tabular}

${ }^{\mathrm{z}}$ Mean separation $(\mathrm{n}=5)$ within columns by Fisher's protected LSD at $P \leq 0.05$.

Table 2. Fruit weight and a* values of 'Red Spur Delicious' as influenced by treatment with a particle film (Yakima, Wash., 1997).

\begin{tabular}{lcc}
\hline \hline & Fruit wt & \\
Treatment & (g/fruit) & $\mathrm{a}^{*}$ value \\
\hline M96-018 (10 applications) & $195 \mathrm{a}^{\mathrm{z}}$ & $21.7 \mathrm{a}$ \\
M96-018 ( 7 applications) & $177 \mathrm{~b}$ & $22.8 \mathrm{a}$ \\
Conventional & $164 \mathrm{c}$ & $21.5 \mathrm{a}$ \\
\hline
\end{tabular}

${ }^{\mathrm{z}}$ Mean separation $(\mathrm{n}=3)$ within columns by Fisher's protected LSD at $P$ $\leq 0.05$.

$\Delta \mathrm{T}$ was not affected by the treatments for either cultivar.

KEARNEYSVILLE, 1998. Yield, fruit harvested per tree, and average fruit weight of 'Empire' were highest when particle film treatments were initiated in May or June compared to the conventional treatment (Table 9). Initiation of particle film treatments in May resulted in higher $\mathrm{a}^{*}$ values compared to all other treatments. SSC, TA, and firmness were not significantly affected by the treatments (data not presented). A was not affected by the treatments on 14 and 18 Aug. and 7 Sept., but was higher for all particle film treatments compared to the conventional treatment on $26 \mathrm{Aug}$. and two of the four particle treatments had higher A that the conventional on 1 Sept. (Table 10). Similarly, leaf $\Delta \mathrm{T}$ was lower for all the particle film treatments compared to the conventional treatment on 26 Aug. and three of the four particle treatments had lower leaf $\Delta \mathrm{T}$ than the conventional on 1 Sept. Leaf chlorophyll content was not affected by the treatments (data not presented).

\section{Discussion}

Six field experiments in semiarid and subhumid environments were conducted to evaluate the effect of a particle film on yield and quality of apple. In two experiments (Kearneysville, 1997, 1998) the trees were not thinned and in both cases fruit set and final fruit number were highest when particle film application was initiated early in the season suggesting that photosynthesis was also increased early in the growing season and decreased fruit abortion.

Table 3. Leaf carbon assimilation, leaf-air temperature differential (leaf-air $\Delta \mathrm{T}$ ), canopy-air temperature differential (canopy-air $\Delta \mathrm{T}$ ), stomatal conductance, and stem water potential for 'Starkrimson Delicious' trees treated with a particle film treatment and measured at 1000 and 1400 HR (Kearneysville, W. Va., 1997).

\begin{tabular}{|c|c|c|c|c|c|c|c|c|c|c|}
\hline \multirow[b]{2}{*}{ Treatment } & \multicolumn{2}{|c|}{$\begin{array}{c}\text { Carbon } \\
\text { assimilation } \\
\left(\mu \mathrm{mol} \cdot \mathrm{m}^{-2} \cdot \mathrm{s}^{-1}\right)\end{array}$} & \multicolumn{2}{|c|}{$\begin{array}{c}\text { Leaf-air } \\
\Delta \mathrm{T} \\
\left({ }^{\circ} \mathrm{C}\right)\end{array}$} & \multicolumn{2}{|c|}{$\begin{array}{c}\text { Canopy-air } \\
\Delta \mathrm{T} \\
\left({ }^{\circ} \mathrm{C}\right) \\
\text { Time (HR) }\end{array}$} & \multicolumn{2}{|c|}{$\begin{array}{c}\text { Stomatal } \\
\text { conductance } \\
\left(\mathrm{mol} \cdot \mathrm{m}^{-2} \cdot \mathrm{s}^{-1}\right)\end{array}$} & \multicolumn{2}{|c|}{$\begin{array}{c}\text { Stem water } \\
\text { potential } \\
(\mathrm{MPa})\end{array}$} \\
\hline & 1000 & 1400 & 1000 & 1400 & 1000 & 1400 & 1000 & 1400 & 1000 & 1400 \\
\hline M96-018 & $8.75 \mathrm{a}^{\mathrm{z}}$ & $9.54 \mathrm{a}$ & $0.0 \mathrm{a}$ & $-0.1 \mathrm{~b}$ & $-4.5 b$ & $-5.7 b$ & $0.44 \mathrm{a}$ & $0.70 \mathrm{a}$ & $-0.66 b$ & $-0.81 \mathrm{~b}$ \\
\hline Conventional & $6.57 \mathrm{~b}$ & $6.79 b$ & $1.0 \mathrm{~b}$ & $0.8 \mathrm{a}$ & $-3.3 \mathrm{a}$ & $-4.9 \mathrm{a}$ & $0.26 b$ & $0.43 b$ & $-0.60 \mathrm{a}$ & $-0.66 \mathrm{a}$ \\
\hline
\end{tabular}

${ }^{\text {z} M e a n ~ s e p a r a t i o n ~}(\mathrm{n}=8)$ within columns by Fisher's protected LSD at $P \leq 0.05$. Data are pooled for 6 and 8 Aug. 1997.

Table 4. Fruit per tree, fruit weight, yield, and a* values of 'Starkrimson' Delicious fruit as influenced by treatment with a particle film (Kearneysville, W. Va., 1997).

\begin{tabular}{lccc}
\hline \hline Treatment & $\begin{array}{c}\text { Fruit/tree } \\
\text { (no.) }\end{array}$ & $\begin{array}{c}\text { Fruit wt } \\
\text { (g/fruit) }\end{array}$ & $\begin{array}{c}\text { Yield } \\
(\mathrm{kg} / \text { tree })\end{array}$ \\
\hline M96-018 & $382 \mathrm{a}^{\mathrm{z}}$ & $135 \mathrm{a}$ & $51.6 \mathrm{a}$ \\
Conventional & $322 \mathrm{~b}$ & $136 \mathrm{a}$ & $43.7 \mathrm{~b}$ \\
Control & $246 \mathrm{c}$ & $123 \mathrm{~b}$ & $30.1 \mathrm{c}$ \\
\hline
\end{tabular}

${ }^{\mathrm{z}}$ Mean separation $(\mathrm{n}=4)$ within columns by Fisher's protected LSD at $P \leq 0.05$.

Table 5. Size and quality parameters of 'Golden Delicious' fruit from trees treated with a particle film (York Springs, Pa., 1997).

\begin{tabular}{lccc}
\hline \hline Treatment & $\begin{array}{c}\text { Fruit diam } \\
(\mathrm{mm})\end{array}$ & $\begin{array}{c}\text { Russeting } \\
(\%)\end{array}$ & $\begin{array}{c}\text { Russet } \\
\text { rating }^{2}\end{array}$ \\
\hline Conventional & $67 \mathrm{~b}^{\mathrm{y}}$ & $13.8 \mathrm{a}$ & $1.8 \mathrm{a}$ \\
M96-018 $(3 \%)$ & $69 \mathrm{a}$ & $3.3 \mathrm{~b}$ & $1.5 \mathrm{~b}$ \\
M96-018 $(1.5 \%)$ & $67 \mathrm{~b}$ & $2.9 \mathrm{~b}$ & $34.1 \mathrm{~b}$ \\
$\mathrm{~b}^{*}$ value & $34.6 \mathrm{~b}$ & $35.9 \mathrm{a}$
\end{tabular}

${ }^{\mathrm{z}}$ Russet rating: $1=$ no russet; $2=$ raised lenticels; $3=<5 \%$ russet; $4=5 \%$ to $10 \%$ russet; $5=11 \%$ to $25 \%$ russet; $6=>25 \%$ russet on fruit surface. yMean separation $(\mathrm{n}=12)$ within columns by Fisher's protected LSD at $P \leq 0.05$. 
In Kearneysville, fruit weight was not affected in 1997, however in 1998, fruit weight and fruit number were greatest when applications began in May and June. In two of the four experiments where trees were commercially thinned, fruit weight was increased. In Santiago, fruit weight was not affected by the particle film treatment, and fruit number was increased by the May and June application times in Wenatchee.

It appears that the particle film treatment increased the carrying capacity of apple trees in five of the six studies by either increasing fruit set and sizing the remaining fruit to a size equivalent to or larger than the reduced crop load on the conventional treatment, or increasing the size of fruit on trees with limited crop load. Only in Santiago was there not an increase in carrying capacity associated with the particle film treatment, yet leaf A was increased by treatment. Lack of a yield response was due in part to the hand thinning that limited the size of the fruit sink. The improvement in carrying capacity occurred, in large part, by a reduction in the canopy temperature and leaf temperature within the cuvette due to reflection of heat by the particle film. The lower leaf temperature increased A and Gs. Increased A occurred in all experiments except
Wenatchee, 1998. Leaf A at Wenatchee was measured when midday air temperatures were $<25{ }^{\circ} \mathrm{C}$ and the trees were well irrigated and environmental stress was low. The reduction in $\mathrm{A}$ in this study may reflect the $5 \%$ to $10 \%$ reduction in light to the leaf surface reported by Glenn et al. (1999) despite the saturating levels of $P A R$ and suggests that only light, and not other environmental stresses, such as excessive heat limited A. However, the Wenatchee experiment had a significant increase in yield for the May and June application times, demonstrating that at other times of the growing season, A was increased. In all the other experiments, air temperatures were $>30^{\circ} \mathrm{C}$, and even if irrigated, the trees were exhibiting heat stress that was apparently reduced by the particle film and resulted in increased A, Gs, and productivity.

Early work with kaolin evaluated the potential to reduce heat stress. Data from all trials except Wenatchee suggest that transpiration is increased due to increased stomatal conductance contrary to earlier work [Abou-Khaled et al. (1970); Basnizki and Evenari (1975); Doraiswamy and Rosenberg (1974); Moreshet et al. (1979); Rao (1985), Stanhill et al. (1976)]. Stem water potentials from the 1997 Kearneysville experiment were more negative than the con-

Table 6. Fruit yield, number, weight, and color of 'Starkrimson Delicious' apples from trees with varying numbers of applications of M96-018 (Wenatchee, Wash., 1998).

\begin{tabular}{|c|c|c|c|c|}
\hline $\begin{array}{l}\text { Time of } \\
\text { application }\end{array}$ & $\begin{array}{c}\text { Yield } \\
\text { (kg/tree) }\end{array}$ & $\begin{array}{c}\text { Fruit/tree } \\
\text { (no.) }\end{array}$ & $\begin{array}{l}\text { Fruit wt } \\
\text { (g/fruit) }\end{array}$ & $\mathrm{a}^{*}$ value \\
\hline May & $82.0 \mathrm{a}^{\mathrm{z}}$ & $369 \mathrm{a}$ & $222 \mathrm{a}$ & $20.0 \mathrm{a}$ \\
\hline June & $78.2 \mathrm{a}$ & 398 a & $196 \mathrm{a}$ & $19.2 \mathrm{a}$ \\
\hline July & $57.2 \mathrm{ab}$ & $262 \mathrm{~b}$ & $218 \mathrm{a}$ & $20.8 \mathrm{a}$ \\
\hline August & $53.4 \mathrm{ab}$ & $229 \mathrm{bc}$ & $233 a$ & $20.6 \mathrm{a}$ \\
\hline September & $45.8 \mathrm{~b}$ & $203 \mathrm{c}$ & $225 \mathrm{a}$ & $20.5 \mathrm{a}$ \\
\hline Control & $49.6 \mathrm{~b}$ & $237 \mathrm{bc}$ & $209 \mathrm{a}$ & $20.7 \mathrm{a}$ \\
\hline
\end{tabular}

${ }_{\mathrm{z}}$ Mean separation $(\mathrm{n}=6)$ within columns by Fisher's protected LSD at $P \leq 0.05$.

Table 7. Fruit yield, number, weight, and color of 'Oregon Spur' apples from trees with varying numbers of applications of M96-018 (Wenatchee, Wash., 1998).

\begin{tabular}{|c|c|c|c|c|}
\hline $\begin{array}{l}\text { Time of } \\
\text { application }\end{array}$ & $\begin{array}{c}\text { Yield } \\
\text { (kg/tree) }\end{array}$ & $\begin{array}{c}\text { Fruit/tree } \\
\text { (no.) }\end{array}$ & $\begin{array}{l}\text { Fruit wt } \\
\text { (g/fruit) }\end{array}$ & $a^{*}$ value \\
\hline May & $64.8 a^{z}$ & $285 \mathrm{~b}$ & $227 \mathrm{a}$ & $16.9 \mathrm{a}$ \\
\hline June & $76.3 \mathrm{a}$ & $350 \mathrm{a}$ & $218 \mathrm{a}$ & $15.7 \mathrm{a}$ \\
\hline July & $42.0 \mathrm{c}$ & $176 \mathrm{~d}$ & $238 \mathrm{a}$ & $15.7 \mathrm{a}$ \\
\hline August & $55.3 \mathrm{bc}$ & $250 \mathrm{bc}$ & $220 \mathrm{a}$ & $16.2 \mathrm{a}$ \\
\hline September & $47.7 \mathrm{bc}$ & $217 \mathrm{~cd}$ & $219 \mathrm{a}$ & $15.6 \mathrm{a}$ \\
\hline Control & $49.6 \mathrm{bc}$ & $227 \mathrm{~cd}$ & $218 \mathrm{a}$ & $15.1 \mathrm{a}$ \\
\hline
\end{tabular}

${ }^{\mathrm{z}}$ Mean separation $(\mathrm{n}=6)$ within columns by Fisher's protected LSD at $P \leq 0.05$.

Table 8. Leaf carbon assimilation rates and leaf-air temperature differential (leaf-air $\Delta \mathrm{T})\left({ }^{\circ} \mathrm{C}\right)$ of the cuvette for 'Starkrimson Delicious' and 'Oregon Spur Delicious' leaves treated repeatedly with M96-018 (Wenatchee, Wash., 1998).

\begin{tabular}{|c|c|c|c|c|}
\hline \multirow[b]{2}{*}{$\begin{array}{l}\text { Treatment } \\
\text { initiated }\end{array}$} & \multicolumn{2}{|c|}{ Starkrimson Delicious } & \multicolumn{2}{|c|}{ Oregon Spur Delicious } \\
\hline & $\begin{array}{c}\text { Leaf carbon } \\
\text { assimilation } \\
\left(\mathrm{CO}_{2}, \mu \mathrm{mol} \cdot \mathrm{m}^{-2} \cdot \mathrm{s}^{-1}\right) \\
\end{array}$ & $\begin{array}{c}\text { Leaf-air } \\
\quad \Delta \mathrm{T} \\
\left({ }^{\circ} \mathrm{C}\right) \\
\end{array}$ & $\begin{array}{c}\text { Leaf carbon } \\
\text { assimilation } \\
\left(\mathrm{CO}_{2}, \mu \mathrm{mol} \cdot \mathrm{m}^{-2} \cdot \mathrm{s}^{-1}\right) \\
\end{array}$ & $\begin{array}{c}\text { Leaf-air } \\
\Delta \mathrm{T} \\
\left({ }^{\circ} \mathrm{C}\right) \\
\end{array}$ \\
\hline No treatment & $11.1 \mathrm{a}^{\mathrm{z}}$ & $1.1 \mathrm{a}$ & $13.5 \mathrm{a}^{\mathrm{z}}$ & $0.6 \mathrm{a}$ \\
\hline May & $10.2 \mathrm{a}$ & $0.0 \mathrm{a}$ & $10.3 \mathrm{c}$ & $1.0 \mathrm{a}$ \\
\hline June & $10.8 \mathrm{a}$ & $0.1 \mathrm{a}$ & $11.3 \mathrm{abc}$ & $0.8 \mathrm{a}$ \\
\hline July & $9.5 \mathrm{a}$ & $0.8 \mathrm{a}$ & $10.6 \mathrm{c}$ & $0.9 \mathrm{a}$ \\
\hline August & $9.4 \mathrm{a}$ & $0.6 \mathrm{a}$ & $11.1 \mathrm{bc}$ & $0.5 \mathrm{a}$ \\
\hline September & $11.2 \mathrm{a}$ & $0.7 \mathrm{a}$ & $13.0 \mathrm{ab}$ & $0.4 \mathrm{a}$ \\
\hline
\end{tabular}

${ }^{\mathrm{z}}$ Mean separation $(\mathrm{n}=36)$ within columns by Fisher's protected LSD at $P \leq 0.05$. Data were pooled for $3 \mathrm{~d}$ of sampling and $2 \mathrm{~h}$ of sampling. 
Table 9. Fruit yield, number, weight, and color of 'Empire' apples on trees treated repeatedly with M96-018 (Kearneysville, W. Va., 1998).

\begin{tabular}{lccc}
\hline \hline $\begin{array}{l}\text { Time of } \\
\text { application }\end{array}$ & $\begin{array}{c}\text { Yield } \\
(\mathrm{kg} / \text { tree })\end{array}$ & $\begin{array}{c}\text { Fruit/tree } \\
(\mathrm{no} .)\end{array}$ & $\begin{array}{c}\text { Fruit wt } \\
(\mathrm{g} / \text { fruit })\end{array}$ \\
\hline May & $34.0 \mathrm{a}^{\mathrm{z}}$ & $275 \mathrm{a}$ & $123 \mathrm{a}$ \\
June & $30.8 \mathrm{~b}$ & $247 \mathrm{a}$ & $124 \mathrm{a}$ \\
July & $27.5 \mathrm{c}$ & $189 \mathrm{~b}$ & $117 \mathrm{~b}$ \\
August & $24.2 \mathrm{~d}$ & $209 \mathrm{ab}$ & $116 \mathrm{~b}$ \\
Control & $27.4 \mathrm{c}$ & $228 \mathrm{ab}$ & $13.7 \mathrm{~b}$ \\
\end{tabular}

${ }^{\mathrm{z}}$ Mean separation $(\mathrm{n}=6)$ within columns by Fisher's protected LSD at $P \leq 0.05$.

Table 10. Leaf carbon assimilation rates (A) $\left(\mathrm{CO}_{2} \mu \mathrm{mol} \cdot \mathrm{m}^{-2} \cdot \mathrm{s}^{-1}\right)$ and leaf-air temperature differential $(\Delta \mathrm{T})\left({ }^{\circ} \mathrm{C}\right)$ of 'Empire' leaves treated with repeat applications of M96-018 (Kearneysville, W. Va., 1998).

\begin{tabular}{|c|c|c|c|c|c|c|c|c|c|c|}
\hline \multirow{3}{*}{$\begin{array}{l}\text { Treatment } \\
\text { initiated }\end{array}$} & \multicolumn{10}{|c|}{ Date of measurement } \\
\hline & \multicolumn{2}{|c|}{14 Aug. } & \multicolumn{2}{|c|}{18 Aug. } & \multicolumn{2}{|c|}{26 Aug. } & \multicolumn{2}{|c|}{1 Sept. } & \multicolumn{2}{|c|}{7 Sept. } \\
\hline & A & $\Delta \mathrm{T}$ & A & $\Delta \mathrm{T}$ & A & $\Delta \mathrm{T}$ & A & $\Delta \mathrm{T}$ & A & $\Delta \mathrm{T}$ \\
\hline No treatment & $11.6 \mathrm{a}^{\mathrm{z}}$ & $0.8 \mathrm{a}$ & $10.2 \mathrm{a}$ & $-0.7 \mathrm{a}$ & $6.9 \mathrm{~b}$ & $2.5 \mathrm{a}$ & $9.1 \mathrm{~b}$ & $0.0 \mathrm{a}$ & $7.8 \mathrm{a}$ & $1.7 \mathrm{a}$ \\
\hline May & $11.9 \mathrm{a}$ & $0.9 \mathrm{a}$ & $11.5 \mathrm{a}$ & $0.0 \mathrm{a}$ & $9.7 \mathrm{a}$ & $1.1 \mathrm{~b}$ & $10.9 \mathrm{a}$ & $-0.7 \mathrm{~b}$ & $8.3 \mathrm{a}$ & $1.5 \mathrm{a}$ \\
\hline June & $12.2 \mathrm{a}$ & $0.8 \mathrm{a}$ & $11.1 \mathrm{a}$ & $-0.4 \mathrm{a}$ & $10.1 \mathrm{a}$ & $1.5 \mathrm{~b}$ & $10.5 \mathrm{~b}$ & $-0.5 \mathrm{~b}$ & $7.9 \mathrm{a}$ & $1.5 \mathrm{a}$ \\
\hline July & $12.1 \mathrm{a}$ & $0.9 \mathrm{a}$ & $11.0 \mathrm{a}$ & $-0.6 \mathrm{a}$ & $9.9 \mathrm{a}$ & $1.5 \mathrm{~b}$ & $10.4 \mathrm{ab}$ & $-0.2 \mathrm{ab}$ & $7.3 \mathrm{a}$ & $1.8 \mathrm{a}$ \\
\hline August & $12.4 \mathrm{a}$ & $0.8 \mathrm{a}$ & $10.3 \mathrm{a}$ & $-0.6 \mathrm{a}$ & $9.3 \mathrm{a}$ & $1.5 \mathrm{~b}$ & $10.8 \mathrm{a}$ & $-0.4 \mathrm{~b}$ & $7.6 \mathrm{a}$ & $1.7 \mathrm{a}$ \\
\hline
\end{tabular}

${ }^{\mathrm{z}}$ Mean separation $(\mathrm{n}=6)$ within columns by Fisher's protected LSD at $P \leq 0.05$.

ventional treatments and demonstrate that a greater water potential gradient was linked to increased stomatal conductance and was driving greater transpiration. While the lower leaf temperature would reduce the leaf-to-air vapor pressure deficit, the increased stomatal conductance is the key parameter controlling actual transpiration. Previous work also documented reduced A due to kaolin application under high temperature conditions [Abou-Khaled et al. (1970); Basnizki and Evenari (1975); Doraiswamy and Rosenberg (1974); Moreshet et al. (1979); Rao (1985), Stanhill et al. (1976)] which does not occur with this particle film. Only under ideal conditions' of air temperatures not exceeding $25^{\circ} \mathrm{C}$ and thorough irrigation at Wenatchee did we observe reduced $\mathrm{A}$, which may be due to reduced light penetration through the particle film. The increase in crop load, fruit weight, and Gs also suggests that water use was greater with the particle film treatments. In the future, irrigation scheduling may need to be modified for particle film treatments in order to insure adequate water availability.

In all the east coast trials and in Santiago, a* values were improved by the particle film, but not in any of the Washington trials. Because the particle film reduced fruit surface temperature in Santiago, it is likely that the color response is due partly to temperature reduction, however, the mechanisms are unclear. Particle application beginning in May 1998 or May 1997 in Kearneysville resulted in higher $\mathrm{a}^{*}$ values, while application beginning in June, July, or August 1998 did not affect a* values. Color development is a late season developmental process and why a season-long application was effective requires more research; however, the response was consistent over 2 years for different cultivars. Residue levels on fruit were similar at harvest for all the time of application experiments in 1998 (data not presented). Therefore, the color response is not entirely due to less residue in the latter portion of the growing season. In the Kearneysville 1997 experiment, the control treatment had $\mathrm{a}^{*}$ values similar to the particle film treatment, however, this was due likely to defoliation by pest damage that greatly increased light penetration into the canopy.

Application of mineral particles to plants was not considered an effective means of reducing heat load in the past based on the literature in the 1970s and 1980s because, ultimately, A was reduced due to particle shading of the leaf. New technology can now modify mineral particles to make them more light transmissive and we have found that these new reflective particles not only reduce the heat load on plants but promote increased $A$ as a result of the reduced heat stress.

\section{Literature Cited}

Abou-Khaled, A., R.M. Hagan, and D.C. Davenport. 1970. Effects of kaolinite as a reflective antitranspirant on leaf temperature, transpiration, photosynthesis, and wateruse efficiency. Water Resources Res. 6:280-289.

Basnizki, J. and M. Evenari. 1975. The influence of a reflectant on leaf temperature and development of the globe artichoke (Cynara scolymus L.). J. Amer. Soc. Hort. Sci 100:109-112.

Doraiswamy, P.C. and N.J. Rosenberg. 1974. Reflectant induced modification of soybean canopy radiation balance. I. Preliminary tests with a kaolinite reflectant.

Agron. J. 66:224-228.

Farmer, A.M. 1993. The effect of dust on vegetation-A review. Environ. Pollution 79:63-75.

Glenn, D.M., G.J. Puterka, T. vanderZwet, R.E. Byers, and C. Feldhake. 1999. Hydrophobic particle films: A new paradigm for suppression of arthropod pests and plant disease. J. Econ. Entom. 92:759-771.

Hirano, T., M. Kiyota, and I. Aiga. 1995. Physical effects of dust on leaf physiology of cucumber and kidney bean plants. Environ. Pollution 89:255-261.

MacKinney, G. 1941. Absorption of light by chlorophyll solutions. J. Biol. Chem. 140:315-322.

Moreshet, S., Y. Cohen, and M. Fuchs. 1979. Effect of increasing foliage reflectance on yield, growth, and physiological behavior of a dry land cotton crop. Crop Sci. 19:863868.

Rao, N.K.S. 1985. The effects of antitranspirants on leaf water status, stomatal resistance and yield in tomato. J. Hort. Sci. 60:89-92.

Sekutowski, D., D.M. Glenn, and G. Puterka. 1998. An aqueous dispersion of a particulate solid having a hydrophobic outer surface and films produced thereby. U.S. Patent 5,908,708.

Soundara Rajan, M.S., K. Ramkumar Reddy, R. Sudhakar Rao, and G.H. Sankara Reddi. 1981. Effect of antitranspirants and reflectants on pod yield of rainfed groundnut. Agr. Sci. Dig. 1:205-206.

Stanhill, G., S. Moreshet, and M. Fuchs. 1976. Effect of increasing foliage and soil reflectivity on the yield and water use efficiency of grain sorghum. Agron. J. 68:329332. 